\title{
A review on the current fisheries management system in Manipur with special reference to LoktakLake
}

\author{
Nongmaithem Bijaya Lakshmi Devi ${ }^{1}$, Ajit Kumar Ngangbam ${ }^{2}$, Nitya Naibedya \\ Biswal $^{3}$ \\ ${ }^{\prime}$ Central Institute of Fisheries Education (CIFE), Fisheries Economics Extension and statistics Division, P.O. \\ Box 400061, Mumbai, India \\ ${ }^{2}$ EUMAINE, Belgium, ${ }^{3}$ ECOHYD, University of Algarve, Portugal
}

\begin{abstract}
Fish and fisheries constitute an important place in the health and wealth of Manipur. The current fish production of Manipur is very low and it still needs to put tremendous effort for increasing its productivity. Among the various water bodies Loktak acts as the major contributor in fish production of Manipur and mostly capture based fisheries were developed around it. While looking into the management aspect it can be address that with the current scenario of the Loktak Lake, the management activities are still lacking and no prominent rules and policies were imposed and followed. Gillnet and dugout canoes were mostly used as fishing craft and gear but again there were no regulations set so far on the uses of the craft and gear. Marketing channels were very short and the transportation is not smooth enough for the fishers. Fishers also faced a lot of problem while fishing in Loktak Lake due to Phum movement on the lake.
\end{abstract}

\section{Introduction:}

Manipur is one of the states located in the North eastern part of India with Imphal as state capital. It is surrounded by Burma in the east which is also the borders of the country, Assam in the west, Nagaland in the north, and Mizoram in the south. The state lies at latitude of $23^{\circ} 83^{\prime} \mathrm{N}-25^{\circ} 68^{\prime} \mathrm{N}$ and longitude of $93^{\circ} 03^{\prime} \mathrm{E}-$ $94^{\circ} 78^{\prime} \mathrm{E}$. The state covered a total of $22,347 \mathrm{~km}^{2}$. Since Manipur is a hilly and landlocked area it has a water body of freshwater origin only. Along with agricultural activities fisheries also constitute one of the livelihood activities of the rural population of the state. According to Manipur fisheries department, 2009-2010 report, the state has its total fish production of about 19,200 tonnes/ yr and has a very high demand for fish as fish occupy the main dishes in all the festivals and celebrations. The fish production of the state is mostly contributed by the LoktakLake which is the largest freshwater lake in northeast India and the only floating lake in the world because of the deposition of huge masses of vegetation, soil and organic matter known as Phumdi floating on it. All the major rivers in Manipur drain into the Loktak Lake and therefore it acts as an accumulation point of all the solid waste deposits carried over by the rivers. In addition to this the construction of Ithai Barrage and the commissioning of the Loktak hydroelectric project however, brought about changes in the fish and fisheries of Loktak Lake. Migratory fishes have, since then, disappeared (Singh, 1991a and 1993). To take care of the problems raised on the health of the Loktak Lake, Government of Manipur has set up the Loktak Development Authority (LDA) under "The Manipur Loktak Lake (Protection) Act, 2006 (Manipur Act 3 of 2006)" with the objective "to provide for administration, control, protection, improvement, conservation and development of the natural environment of the Loktak lake and for matters connected with as incidental thereto."

Fisheries management can be related with different activities of the fishers and the rules specified for them while doing their activities. Rao (1972) defined fish marketing as all those economic activities performed from the point of catching fish to the point of final consumption. Caddy and Mahon (1995) had stated that fisheries management involves regulating when, where, how, and how much fishermen are allowed to harvest to ensure that there will be fish in the future. Anon (1997) reported that improvement in the post harvest utilization of the fish catch can ensure further nutritional security among a wide range of people in our country.

\section{Fisheries Management}

Devi et. al. (2012) stated that the livelihood of fishermen inhabited around the Loktak Lake were entirely dependent on the fishes caught from the lake. They caught the fishes at anytime from any part of the lake since the Government had not set any limited fishing area for the fishermen. Moreover, there was no leasing system followed in the entire water body of the lake. Moreover, banned seasons are so far does not exist in Loktak Lake. While taking thesuggestion of the fishers regarding the existence of banned season, 80 percent were having negative response stating that they do not have any alternative source of livelihood whereas 20 percent had positive response towards it. All (100\%) the fishers had stated that there were sharp decline in the fish catch of Loktak Lake with the construction of Ithai barrage. Many of the indigenous species had disappeared since then. Biaklun et. al. (2009) reported that Phum fishing is very extensively practised in Loktak 
A review on the current fisheries management system in Manipur with special reference to...

Lake and is a characteristic feature of Loktak Lake. The number of Athaphums (Phum circles for fishing purpose) has increased considerably after the construction of Ithai barrage. Further the report adds that as per remote sensing imageries, the number of Athaphums has increased from 217 in 1990 to 3019 in February 1999. Singh (1996) in his study on socioeconomic development of Bisnupur district (Manipur) found out that fishing season in the Loktak Lake consists of two seasons namely summer season which last from March to August and winter season last from September to February. Even though the fishing periods consist of two seasons, the fishing activities remain continuous throughout the year i.e. with the end of the first season, the second season starts immediately. In other words banned periods for fishing activities do not exist in this lake.

Biaklun et. al. (2009) reported that several types of fishing gears are used in the State. The main fishing gears include gill nets (mesh size ranging from $15 \mathrm{~mm}-140 \mathrm{~mm}$ ), multi-pronged spear, dip nets, lift nets, cast nets, scoop nets, hooks and gorges, traps, drive in nets etc. Gill nets are in the traditional fishing craft out of all these fishing gears. There are about 2,800 canoes being used for fishing and navigation purposes in Loktak Lake. On the other hand, Devi et. al. (2012) reported that gears were said to be selective only for different sizes of fishes but not for species. Gill nets of different mesh size were found to be operated ranging from $13 \mathrm{~mm}-110 \mathrm{~mm}$ available at a price range between Rs. 350 to Rs. 450 . The traps used were having the size range from 2-4 ft. with a mesh size of 0.5-1 inches width and 2-4ft.length available at prices ranging from Rs. 50 to 60 . Gill nets were mainly made from polyethylene fibres and dip nets from nylon and traps were made from bamboo. And in case of craft dugout canoes with single log or double log were mainly operated in the Loktak Lake. These canoes were mainly constructed from local wood known as Uningthou (Phoebe hensiana) and there were no particular operational month, thus fishing activities were operated throughout the year according to the change in the colour of the water that indicates the availability of the fishes. Canoes were operated once or twice in a day especially in the morning hours and generally landed at noon. Singh (1981) in his study on fishing crafts and gears of Manipur had found out that Dugout canoes with single log and plank build (made by joining planks) were mainly operated as fishing craft in Loktak Lake of Manipur. Further he also found out that fishing gears used in Manipur in summer season consist of dip net, small dip net, rod and line. Beside these traps scooping net, long line and cast net were used. In winter large gill net and Phumthaba are used. Additional gear such as scoop net, long line and cast net were operated throughout the year. Singh (1977) had found out that wood such as tairen, uningthou, ton-tolhou and mango are also used for the construction of fishing canoe both as dugout canoes and plank build canoes. The use of teak for the construction of fishing canoe is not common, even though very few are constructed. This is because of the high cost of this wood and also less availability. Singh (1999) also reported that the material used for the construction of dugout canoes are large trunks of trees. There are various types of woods locally used for the canoe construction in Manipur. Cham - Artocarpus chaplasha, Tairel - Cedrella tuna, Teak - Tectona grandis - because of its high price it is not commonly used, Uningthou - Phoebe hensiana, Tan - tolhau - Terminalia myriocarpa, Mango - Mangifera indica.

Devi (1997) had studied the present status of the fish and fisheries of Loktak Lake. She had concluded that the word 'trash' or 'waste' fish is not known in the state and all the sizes of the fish ranging from $1 \mathrm{~cm}$ to $100 \mathrm{~cm}$ have market value except spoiled ones. Singh (1982) in his study on trading pattern of commercially important fishes in Manipur had found out that most of the fishes marketed were coming from Loktak Lake, Ikop, Kharung Pat, Pumlen and the price of the different varieties of fishes were different in different markets in the same season. Also he had found out that the price of the fresh fishes particularly live fishes which are commercially important in the fish market of Manipur fluctuates according to the season. During the gut season, the price lowers down to the minimum while in the lean season it shoots up to the maximum beyond the reach of common people. Devi (2011) had found out that nearly 46.67 percent of the fishers marketed the fish through middlemen and there were no existence of commission agents found. She further interprets that this may be due to the fact that majority of the fishers did not have time to go to the main market for selling the fishes. The fishers went for fishing in morning and then, after returning they had to segregate the fishes for smoking and for selling in fresh condition by separating them species wise or size wise. After all these activities, most of them had to give it to the middlemen for sale. For those families having more number of members they used to go to the main market for marketing it. Vaiphei (1977) in his study on fish and fisheries of Manipur had pointed out that the present marketing system of fish in the state is not satisfactory as there is no ice plant factory in the state and fish being the highly perishable commodity, the fish merchant as well as the consumer are greatly affected due to spoilage. Singh (1978) in his study on fish marketing in Manipur had found out that in Manipur, marketing system is still functioning in the old traditional form. For development of the market, the following practices are deemed necessary i.e. icing facilities, transportation, ensuring regular supply of good quality fish at reasonable price fixed by the Government, installation of proper fish stall and adopting best type of culture practice to boost up the production. 


\section{Problems Of The Loktak Lake And The Fishers}

Devi (2011) address from her study that fishermen faced lots of problems during fishing. Due to strong waves, phums destroyed many gears and crafts. Sometimes the wind directions were found rushing the phums all over suddenly and it stuck the boats or persons which lead to death or injury, or it blocked their way to home. Other problems faced were cyclones, construction of Ithai barrage which decreased the fish catch and clearing of phum which in turn increases the waves. Singh et al. (2009) studied on phumdi proliferation: a case study of Loktak Lake, Manipur and the results showed that the phumdi area has increased from 1989 to 2002. The main causes for phumdi proliferation were the construction of the Ithai Barrage Dam, increase in athaphum fishing, pollution, growth of settlements on phumdis, etc. It was the human pressure that has aided in the growth of phumdis. Singh (1995) in his study on Loktak Hydroelectric Project vis-à-vis development of fisheries in Manipur had revealed that with the construction of Ithai barrage on the down stream of Manipur river to maintain sufficient water in the Loktak Lake for the generation of hydroelectricity, most of the indigenous species have disappeared from the catch and many agricultural land were inundated and unsuitable for agriculture. Sharma (2009) in his study on agricultural marketing system in Northeastern states of India reported that due to motor roads do not properly connect most of the production areas in Manipur, farmers are facing lots of difficulty to bring their produce to the primary or terminal markets for sale and thus deprive themselves of remunerative prices. Moreover during the monsoon season due to bad road conditions and tear of landslides, the transport charges are very high. Therefore inadequate transport facility causes glut in the producing area and scarcity in the consuming centres. Singh and Khundrakpam (2009) in his study on phumdi proliferation of Loktak Lake, Manipur had found out that the phumdi area has increased from 1989 to 2002. Singh et al. (2010) in his study on modelling the impact of prescribed global warming on water resources for Loktak Lake had found out that climate change is likely to have major implications for wetland ecosystems, which will include altered water level regimes due to modifications in local and catchment hydrology. The higher water levels are likely to exacerbate existing ecological deterioration within the lake as well as enhancing the problems of flooding of lakeside communities.

\section{Conclusion}

Since Manipur has large water body, it has more scope and potential for fish production. At present the state is importing the fishes from the neighbouring states like Assam and West Bengal. This can be made self sufficiency by focusing on proper management and development activities. In most cases, it is quite alarming that fisheries management and development strategies have failed to reverse the trend of poverty and resource over exploitation and degradation. Number of factors including the open access nature of the resource without proper regulations can be attributed. Setting up of the rules and regulations in such a way accepted by the fisher and for the nature is very much essential for the health of the water body and sustainable productivity. Without proper management the wealth provided by the nature may be permanently lost someday from this earth. Therefore, it is always better to save the ecosystem before it enters to the worst situation rather than restoring it at the later stage which may be impossible at some point of time for which the role and intervention of the state and central government policy makers along with the State Department is highly demanded as a joint effort.

\section{Reference}

[1] Anon, A survey on dry fish processing in the east and west coast of India, Survey report for the DFID Post- Harvest Research Programme. Central Institute of Fisheries Technology, 1997.

[2] P.K. Biaklun, A. Ngangbam. and N. Basavaraja, Status of aquaculture and fisheries in Manipur. Fishing Chimes, 29(1), 2009, $102-$ 104.

[3] J.F. Caddy.and R. Mahon, Reference points for fisheries management. FAO Fisheries technical paper 347, Rome. ISBN 92-5, 1995, 103733-7.

[4] N.B.L Devi, Study of fishers' livelihood and fisheries management in Loktak lake region of Manipur, Unpub. M.F.Sc (thesis), Central institute of Fisheries Education, Mumbai, 2011.

[5] R.K.S. Devi, Observation on the present status of the Fish and Fisheries of Loktak Lake in Manipur and suggestion to improve its productivity. Unpub. D.F.Sc (dissertation), C.I.F.E, Mumbai, 1997.

[6] Department of Fisheries, Govt. of Manipur, 2009-2010

[7] P.S. Rao, Problems of management of fish marketing and co-operatives, FAO/SIDA Course on the management of fishermen's cooperatives, 1972.

[8] A.K. Singh, Socioeconomic development of few fishing village-A case study of Bisnupur district (Manipur).Unpub. D.F.Sc (dissertation), Central institute of Fisheries Education, Mumbai, 1996.

[9] A.L. Singh. and M.L. Khundrakpam, Phumdi proliferation: a case study of Loktak lake, Manipur, Water and Environment Journal, 25(1), 2009, 99-105

[10] C.R. Singh, J. R. Thompson, J. R. French, D. G. Kingston, A. W. Mackay, Modelling the impact of prescribed global warming on water resources of headwater catchments of the Irrawaddy River and their implications for Loktak Lake, northeast India, Hydrology and Earth System Sciences Discussions, 7(3), 2010, 2781-2828.

[11] N.B.L. Devi., A.K. Ngangbam. and S. Immanuel, A study on existing fisheries management system and the problems faced by the fishers in Loktak lake of Manipur, IOSR Journal of Agriculture and Veterinary Science, 1(5),2012, 22-28.

[12] R.K.S. Singh, Project report of survey, documentation and validation of infra-technologies for fishing crafts and gears, 1999. 
A review on the current fisheries management system in Manipur with special reference to...

[13] D.S. Singh, Fish marketing in Manipur. Unpub. D.F.Sc (dissertation), Central institute of Fisheries Education, Mumbai, 1978.

[14] E.S. Singh, Trading pattern of commercially important fishes in Manipur. Unpub.D.F.Sc (dissertation), Central institute of Fisheries Education, Mumbai, 1982.

[15] I.Th. Singh, Loktak Hydroelectric Project vis-à-vis development of fisheries in Manipur.Unpub. D.F.Sc (dissertation), Central institute of Fisheries Education, Mumbai, 1995.

[16] N.B. Singh, An account of the fishing gears of Manipur with special reference to Loktak lake. Unpub. D.F.Sc (dissertation), Central institute of Fisheries Education, Mumbai, 1977.

[17] P.B. Singh, Fishing craft and gear of Manipur. Unpub. D.F.Sc (dissertation), Central institute of Fisheries Education, Mumbai, 1981.

[18] S.K. Singh, Fish and Fisheries of Loktak lake in Manipur. Unpub. D.F.Sc (dissertation), Central institute of Fisheries Education, Mumbai, 1978

[19] T.H. Singh, Study on the biology and Culturable Possibilities of the Indigenous fishes of Manipur, Osteobrama belangiri and Monopterus albus Technical Report, ICAR, New Delhi, 1991a.

[20] T.H. Singh, Impact of Loktak National Hydroelectric project on the Environment of Manipur. Technical Report, Department of Science, Technology and Environment, Government of Manipur, 1993.

[21] K. Vaiphei, Fish and Fisheries of Manipur. Unpub. D.F.Sc (dissertation), Central institute of Fisheries Education, Mumbai, 1977.

[22] Sharma, Agricultural marketing system in Northeastern states. In: Manual on Agricultural Management and Rural Marketing, 2009, $7-15$ 